DEPARTMENT OF THE INTERIOR

U.S. GEOLOGICAL SURVEY

\title{
Principal Facts for 63 Gravity Stations in the Vicinity of Katmai National Park, Alaska
}

by

R.W. Saltus

Open-File Report 92-310

This report is preliminary and has not been reviewed for conformity with U.S. Geological Survey editorial standards. Any use of trade, firm, or product names is for descriptive purposes only and does not imply endorsement by the U.S. Government. 


\section{Abstract}

This report describes data for 63 gravity measurements made in July 1991 in the vicinity of Katmai National Park and the town of King Salmon, Alaska. The measurements were made with Lacoste and Romberg gravity meter G-17C. Elevation control is from mapped spot elevations and altimetry. Included in this report are base station descriptions for two new gravity bases established in King Salmon. Tables in the report list principal facts and reduced Bouguer and isostatic residual gravity anomalies. Page-sized plots at 1:250,000 scale show the measurement site locations. A page-sized contour plot of the complete Bouguer anomaly in the vicinity of Katmai Pass shows a gravity low that may be caused by low-density magma within the crust.

\section{Gravity data collection and reduction}

The tables list 5 gravity base station and 63 field station values for data collected in July 1991 . The stations are located in and around the Katmai National Park and King Salmon-Naknek area, Alaska (Figure 1). The data were obtained as part of a cooperative study between the U.S. Geological Survey (USGS) and the University of Alaska, Fairbanks. Field work was performed in conjunction with maintenance of the seismograph network at Katmai National Park (network described in Ward et al., 1991).

Lacoste and Romberg gravity meter G-17C (a rebuilt version of G-17) was used. Elevation control was mapped spot elevations and altimetry. Stations were reached by helicopter, except the traverse along the highway from King Salmon to Naknek that was done by truck.

Gravity values are tied to David Barnes' (USGS) base station ANCW (personal commun., 1991) in Anchorage (at Elmendorf Air Force Base near the NOAA warehouse). Observed gravity values relative to ANCW at other USGS Anchorage bases (ANCG at the Anchorage Airport parking garage and ANCU at the USGS office in Anchorage) are also listed in table 1. Two new bases were established in King Salmon, KS91A at the Post Office (at the Airport) and KS91B at the U.S. Fish and Wildlife Office (near the Naknek river); Base station descriptions are given in the appendix of this report. Table 1 gives the observed gravity values at these base stations. The base station values are on the International Gravity Standardization Network of 1971 datum (Morelli, 1974).

Bouguer gravity anomalies were calculated using the 1967 Geodetic Reference System formula (International Association of Geodesy, 1971) using methods developed by Barnes $(1972 ; 1984)$ for use in Alaska. A Bouguer reduction density of $2.67 \mathrm{~g} / \mathrm{cm}^{3}$ was used. Terrain corrections were done by computer, using digital topography, from $0.39 \mathrm{~km}$ to $166.7 \mathrm{~km}$ from the station (Plouff, 1977). Inner zone terrain corrections, estimated in the field, were added to the computer corrections. Isostatic anomalies were calculated assuming a local (Airy) isostatic model (Simpson et al., 1986) with the following parameters: crustal density of 2.67 $\mathrm{g} / \mathrm{cm}^{3}$, root depth of $25 \mathrm{~km}$ at sea level, and a density contrast at the root of $0.4 \mathrm{~g} / \mathrm{cm}^{3}$.

The largest potential source of error in the reduced gravity values is from elevation inaccuracy. Elevations were established by altimetry checked against mapped spot elevations on the USGS 1:63,360-scale maps (produced in 1951 with minor revision in 1984). Several of the gravity measurement sites were revisited multiple times during the survey. Based on comparison of repeat altimetry at these sites (mostly USGS seismograph sites as indicated in Table 3), elevations are assumed to be accurate to better than 30 feet. A 30 foot elevation error produces an error in the combined free air and Bouguer correction of about $1.8 \mathrm{mGal}$.

Table 2 gives principal facts and reduced anomalies for a gravity traverse along the highway from King Salmon to Naknek, Alaska. Elevation control is by altimetry. The first 4 letters of the station name give 
the name used in the field, the second 4 letters are the name as changed for inclusion in the Alaska gravity data base (field names had to be changed to avoid name duplication in the data base). Figure 2 shows the location of the gravity stations.

Table 3 contains principal facts and reduced gravity values for stations in and around Katmai National Park. Several of the stations are located at sites of the seismograph network (Ward et al., 1991). The three-letter designations listed in the "Loc" column are names of the seismograph stations. In addition, several measurement sites were placed in an attempt to relocate measurement sites of an earlier, local survey in the Novarupta region (Eichelberger et al., 1990). These sites are indicated with site numbers in the "Loc" column. It was not possible to relocate the buried metal bars that marked these sites, so locations were estimated from site descriptions. Figures 2 through 5 show the locations of the stations in and around Katmai National Park.

Table 1: Base Station Values.

$O G=$ Observed Gravity, $F A A=$ Free Air Anomaly, $S B A=$ Simple Bouguer Anomaly (density $2.67 \mathrm{~g} / \mathrm{cm}^{3}$ ), $T C=$ Terrain Correction, $C B A=$ Complete Bouguer Anomaly, ${ }^{*}=$ no terrain correction calculated.

\begin{tabular}{|c|c|c|c|c|c|c|c|c|c|c|}
\hline \multirow[t]{2}{*}{ Station } & \multicolumn{2}{|c|}{ Latitude } & \multicolumn{2}{|c|}{ Longitude } & \multirow{2}{*}{$\begin{array}{r}\text { Elev. } \\
\text { feet }\end{array}$} & \multirow[t]{2}{*}{$O G$} & \multirow{2}{*}{\multicolumn{2}{|c|}{ gravity in $\mathrm{mGal}$}} & \multirow[t]{2}{*}{$T C$} & \multirow[t]{2}{*}{$C B A$} \\
\hline & deg & $\min$ & deg & $\min$ & & & & & & \\
\hline ANCW & 61 & 14.00 & 149 & 46.00 & 204 & 981930.17 & -63.3 & -70.2 & .7 & -69.5 \\
\hline ANC & 61 & 11.00 & 149 & 59.0 & 80 & 981907.49 & -93.8 & -96.5 & * & * \\
\hline ANCU & 61 & 11.00 & 149 & 48.00 & 200 & 981930.40 & -59.6 & -66.4 & * & * \\
\hline KS91A & 58 & 41.00 & 156 & 39.74 & 50 & 981827.81 & 20.3 & 18.6 & .0 & 18.6 \\
\hline KS91B & 58 & 40.78 & 156 & 39.84 & 30 & 981829.26 & 20.2 & 19.2 & .0 & 19.2 \\
\hline
\end{tabular}

Table 2: Katmai to Naknek traverse.

$O G=$ Observed Gravity, $F A A=$ Free Air Anomaly, $S B A=$ Simple Bouguer Anomaly (density $2.67 \mathrm{~g} / \mathrm{cm}^{3}$ ), $T C=$ Terrain Correction, $C B A=$ Complete Bouguer Anomaly, $I S O=$ Isostatic Residual Gravity Anomaly.

\begin{tabular}{|c|c|c|c|c|c|c|c|c|c|c|c|}
\hline \multirow[t]{2}{*}{ Station } & \multicolumn{2}{|c|}{ Latitude } & \multicolumn{2}{|c|}{ Longitude } & \multirow{2}{*}{$\begin{array}{r}\text { Elev. } \\
\text { feet }\end{array}$} & \multirow[t]{2}{*}{$O G$} & \multirow[t]{2}{*}{$F A A$} & \multirow{2}{*}{\multicolumn{2}{|c|}{$\begin{array}{l}S B A \quad T C \\
\text { ty in } m G a l\end{array}$}} & \multirow[t]{2}{*}{$C B A$} & \multirow[t]{2}{*}{ ISO } \\
\hline & deg & $\min$ & deg & $\min$ & & & & & & & \\
\hline KS01KA41 & 58 & 42.36 & 156 & 38.01 & 65 & 981829.49 & 21.6 & 19.4 & .0 & 19.4 & 23.8 \\
\hline KS02KA42 & 58 & 43.11 & 156 & 39.14 & 75 & 981829.97 & 22.0 & 19.5 & .0 & 19.5 & 23.7 \\
\hline KS03KA43 & 58 & 44.08 & 156 & 41.33 & 65 & 981827.88 & 17.7 & 15.5 & .0 & 15.5 & 19.5 \\
\hline KS04KA44 & 58 & 44.60 & 156 & 44.31 & 80 & 981821.97 & 12.5 & 9.8 & .0 & 9.8 & 13.5 \\
\hline KS05KA45 & 58 & 44.80 & 156 & 49.24 & 125 & 981820.19 & 14.7 & 10.4 & .0 & 10.4 & 13.5 \\
\hline KS06KA46 & 58 & 45.00 & 156 & 54.13 & 135 & 981829.99 & 25.1 & 20.5 & .0 & 20.5 & 23.1 \\
\hline KS07KA47 & 58 & 44.99 & 156 & 56.95 & 90 & 981836.01 & 26.9 & 23.9 & .0 & 23.9 & 26.2 \\
\hline KS08KA48 & 58 & 43.49 & 157 & 3.23 & 85 & 981831.29 & 23.8 & 20.9 & .0 & 20.9 & 22.6 \\
\hline KS09KA49 & 58 & 43.66 & 157 & 1.04 & 70 & 981833.76 & 24.6 & 22.2 & .0 & 22.2 & 24.1 \\
\hline
\end{tabular}


Table 3: Katmai Region Gravity Data.

$O G=$ Observed Gravity, $F A A=$ Free Air Anomaly, $S B A=$ Simple Bouguer Anomaly (density $2.67 \mathrm{~g} / \mathrm{cm}^{3}$ ), $T C=$ Terrain Correction, $C B A=$ Complete Bouguer Anomaly, $I S O=$ Isostatic Residual Gravity Anomaly .

\begin{tabular}{|c|c|c|c|c|c|c|c|c|c|c|c|c|}
\hline \multirow[t]{2}{*}{ Station } & \multirow[t]{2}{*}{ Loc } & \multicolumn{2}{|c|}{ Latitude } & \multicolumn{2}{|c|}{ Longitude } & \multirow{2}{*}{$\begin{array}{r}\text { Elev. } \\
\text { feet }\end{array}$} & \multirow[t]{2}{*}{$O G$} & \multirow{2}{*}{\multicolumn{3}{|c|}{$\begin{array}{crr}A A & S B A & T C \\
\text { gravity in } & m G a l\end{array}$}} & \multirow[t]{2}{*}{$C B A$} & \multirow[t]{2}{*}{ ISO } \\
\hline & & deg & $\min$ & $\operatorname{deg}$ & $\min$ & & & & & & & \\
\hline WWW KA0A & WWW & 58 & 20.75 & 156 & 20.68 & 1363 & 981730.52 & 73.9 & 27.4 & 6.0 & 33.4 & 40.8 \\
\hline GRANKA0B & & 58 & 22.78 & 156 & 16.32 & 1683 & 981718.91 & 89.6 & 32.2 & 8.4 & 40.6 & 49.1 \\
\hline KSM KA0C & KSM & 58 & 50.80 & 156 & 12.93 & 1840 & 981724.52 & 72.4 & 9.6 & 16.2 & 25.8 & 35.7 \\
\hline KM01KA51 & & 58 & 17.15 & 155 & 8.85 & 3786 & 981510.53 & 86.8 & -42.3 & 15.0 & -27.3 & -2.4 \\
\hline KM02KA52 & 250 & 58 & 16.36 & 155 & 8.95 & 3235 & 981544.04 & 69.5 & -40.8 & 5.7 & -35.1 & -10.2 \\
\hline KM03KA53 & & 58 & 16.87 & 155 & 5.04 & 2310 & 981611.98 & 49.7 & -29.1 & 7.2 & -21.9 & 3.4 \\
\hline KM04KA54 & KCG & 58 & 18.52 & 155 & 6.43 & 2130 & 981628.48 & 47.0 & -25.6 & 7.5 & -18.1 & 7.8 \\
\hline KM05KA55 & & 58 & 15.59 & 155 & 16.27 & 2110 & 981623.34 & 44.0 & -28.0 & 4.6 & -23.4 & .6 \\
\hline KM06 & & 58 & 13.63 & 155 & 14.75 & 3690 & 981515.01 & 87.0 & -38.9 & 13.6 & -25.3 & -2.3 \\
\hline KMO & & 58 & 14.63 & 155 & 12.43 & 3102 & 981550.92 & 66.2 & -39.6 & 6.6 & -33.0 & -9.0 \\
\hline KM & KVT & 58 & 22.91 & 155 & 17.72 & 1615 & 981670.89 & 35.0 & -20.0 & 3.5 & -16.5 & 8.3 \\
\hline $\mathrm{KM}$ & & 58 & 17.32 & 155 & 11.71 & 2540 & 981601.40 & 60.2 & -26.5 & 3.9 & -22.6 & 2.4 \\
\hline$A 60$ & KBM & 58 & 16.11 & 155 & 12.27 & 2240 & 981616.87 & 49.0 & -27.4 & 3.4 & -24.0 & .6 \\
\hline A61 & KKP & 58 & 13.05 & 155 & 9.63 & 2175 & 981599.51 & 29.7 & -44.5 & 6.4 & -38.1 & -14.7 \\
\hline A62 & & 58 & 17.56 & 155 & 19.25 & 1250 & 981684.50 & 21.5 & -21.1 & 5.8 & -15.3 & 9.1 \\
\hline A63 & & 58 & 15.49 & 155 & 19.32 & 1395 & 981672.10 & 25.6 & -22.0 & 8.0 & -14.0 & 9.8 \\
\hline A64 & & 58 & 20.33 & 155 & 20.78 & 960 & 981708.41 & 14.4 & -18.3 & 4.0 & -14.3 & 10.1 \\
\hline A65 & & 58 & 17.09 & 155 & 41.62 & 1355 & 981693.72 & 41.3 & -4.9 & 1.8 & -3.1 & 16.1 \\
\hline KM16KA66 & & 58 & 10.12 & 155 & 7.87 & 3115 & 981557.03 & 79.7 & -26.6 & 14.7 & -11.9 & 8.9 \\
\hline KM17KA67 & & 58 & 8.43 & 155 & 10.98 & 2865 & 981565.28 & 66.7 & -31.0 & 16.6 & -14.4 & 5.1 \\
\hline KM18KA68 & & 58 & 8.70 & 155 & 15.39 & 2490 & 981600.10 & 65.8 & -19.1 & 7.3 & -11.8 & 8.1 \\
\hline KM19KA69 & & 58 & 9.32 & 155 & 17.93 & 3905 & 981514.51 & 112.6 & -20.6 & 10.9 & -9.7 & 10.3 \\
\hline KM20KA70 & & 58 & 10.18 & 155 & 19.63 & 4980 & 981444.01 & 142.1 & -27.8 & 17.5 & -10.3 & 10.0 \\
\hline KM21KA71 & KTR & 58 & 12.51 & 155 & 4.67 & 2350 & 981607.14 & 54.5 & -25.6 & 6.7 & -18.9 & 3.8 \\
\hline KM22KA72 & $\mathrm{KMC}$ & 58 & 11.18 & 155 & 9.08 & 1620 & 981643.07 & 23.6 & -31.7 & 5.3 & -26.4 & -4.3 \\
\hline KM23KA73 & KTP & 58 & 5.54 & 155 & 9.84 & 2675 & 981586.14 & 73.6 & -17.7 & 11.8 & -5.9 & 10.9 \\
\hline KM24KA74 & & 58 & 8.33 & 155 & 21.16 & 3810 & 981518.68 & 109.1 & -20.8 & 12.1 & -8.7 & 10.5 \\
\hline KM25KA75 & & 58 & 6.01 & 155 & 23.15 & 2670 & 981584.03 & 70.3 & -20.7 & 12.5 & -8.2 & 9.3 \\
\hline KM26KA76 & & 58 & 7.43 & 155 & 26.24 & 3855 & 981511.48 & 107.4 & -24.1 & 17.1 & -7.0 & 11.2 \\
\hline KM27KA77 & & 58 & 13.81 & 155 & 2.09 & 3880 & 981516.03 & 105.7 & -26.7 & 8.5 & -18.2 & 4.9 \\
\hline KM28KA78 & & 58 & 16.19 & 154 & 52.85 & 3540 & 981544.02 & 98.4 & -22.3 & 8.6 & -13.7 & 10.4 \\
\hline КМ29КА79 & KKC & 58 & 13.86 & 154 & 53.96 & 1850 & 981654.08 & 52.6 & -10.5 & 7.4 & -3.1 & 19.8 \\
\hline KM30KA80 & KRB & 58 & 31.74 & 154 & 43.30 & 1630 & 981674.27 & 27.9 & -27.7 & 6.0 & -21.7 & 6.4 \\
\hline KM31KA81 & KNE & 58 & 20.29 & 154 & 50.11 & 2950 & 981583.92 & 77.3 & -23.4 & 6.7 & -16.7 & 9.4 \\
\hline KM32KA82 & & 58 & 35.63 & 155 & 19.44 & 1585 & 981694.38 & 38.6 & -15.5 & 7.1 & -8.4 & 14.1 \\
\hline KM33KA83 & KEL & 58 & 26.44 & 155 & 44.24 & 3195 & 981602.17 & 110.3 & 1.3 & 17.2 & 18.5 & 35.9 \\
\hline KM34KA84 & 74 & 58 & 16.42 & 155 & 8.81 & 3290 & 981539.95 & 70.5 & -41.7 & 5.9 & -35.8 & -10.9 \\
\hline KM35KA85 & 113 & 58 & 16.33 & 155 & 8.22 & 2976 & 981568.63 & 69.8 & -31.7 & 4.1 & -27.6 & -2.7 \\
\hline KM36KA86 & 71 & 58 & 15.79 & 155 & 9.94 & 2352 & 981604.58 & 47.7 & -32.5 & 4.8 & -27.7 & -3.0 \\
\hline KM37KA87 & $\mathrm{KCE}$ & 58 & 14.54 & 155 & 11.23 & 2570 & 981582.40 & 47.7 & -39.9 & 4.1 & -35.8 & -11.8 \\
\hline KM38KA88 & KKR & 58 & 5.62 & 155 & 30.27 & 3340 & 981539.37 & 89.3 & -24.6 & 15.3 & -9.3 & 7.3 \\
\hline
\end{tabular}


Table 3 (continued)

\begin{tabular}{|c|c|c|c|c|c|c|c|c|c|c|c|c|}
\hline \multirow[t]{2}{*}{ Station } & \multirow[t]{2}{*}{ Loc } & \multicolumn{2}{|c|}{ Latitude } & \multicolumn{2}{|c|}{ Longitude } & \multirow{2}{*}{$\begin{array}{r}\text { Elev. } \\
\text { feet }\end{array}$} & \multirow[t]{2}{*}{$O G$} & \multirow{2}{*}{\multicolumn{3}{|c|}{$\begin{array}{c}F A A \quad S B A \quad T C \\
\text { gravity in mGal }\end{array}$}} & \multirow[t]{2}{*}{$C B A$} & \multirow[t]{2}{*}{$I S O$} \\
\hline & & deg & $\min$ & deg & $\min$ & & & & & & & \\
\hline KM39KA89 & & 58 & 11.94 & 155 & 29.37 & 2888 & 981578.24 & 77.0 & -21.5 & 16.0 & -5.5 & 15.0 \\
\hline KM40KA90 & & 58 & 12.99 & 155 & 24.46 & 1900 & 981644.76 & 49.1 & -15.7 & 4.1 & -11.6 & 10.3 \\
\hline KM41KA91 & & 58 & 11.81 & 155 & 16.90 & 5970 & 981352.55 & 141.6 & -62.0 & 31.6 & -30.4 & -8.9 \\
\hline KM42KA92 & & 58 & 16.47 & 155 & 1.54 & 4725 & 981460.40 & 126.0 & -35.2 & 11.0 & -24.2 & .4 \\
\hline KM43КА93 & & 58 & 17.44 & 154 & 56.23 & 5070 & 981439.52 & 136.2 & -36.7 & 17.0 & -19.7 & 5.1 \\
\hline KM4 & & 58 & 20.16 & 155 & 2.37 & 4980 & 981443.33 & 127.9 & -42.0 & 22.7 & -19.3 & 6.5 \\
\hline KM4 & & 58 & 21.61 & 155 & 3.49 & 4830 & 981459.51 & 128.0 & -36.7 & 18.3 & -18.4 & 7.7 \\
\hline KM4 & & 58 & 23.82 & 155 & 5.79 & 3205 & 981568.66 & 81.2 & -28.1 & 9.2 & -18.9 & 7.6 \\
\hline KM & & 58 & 24.42 & 155 & 8.70 & 3655 & 981537.94 & 92.1 & -32.6 & 13.7 & -18.9 & 7.1 \\
\hline KM4 & & 58 & 24.67 & 155 & 11.59 & 4535 & 981468.80 & 105.4 & -49.3 & 30.6 & -18.7 & 6.5 \\
\hline KM4 & & 58 & 23.22 & 155 & 13.52 & 4505 & 981472.35 & 108.1 & -45.6 & 29.2 & -16.4 & 8.6 \\
\hline KM50KA50 & & 58 & 26.61 & 155 & 15.77 & 2542 & 981608.89 & 55.3 & -31.4 & 12.2 & -19.2 & 5.4 \\
\hline KM51KA0D & & 58 & 22.16 & 155 & 25.56 & 945 & 981718.87 & 21.0 & -11.3 & 2.3 & -9.0 & 14.3 \\
\hline
\end{tabular}

\section{Bouguer gravity in the vicinity of Katmai Pass}

The gravity data reported here were collected to investigate the boundaries of the gravity low identified by previous studies in the vicinity of Katmai National Park (Kienle, 1969; David Barnes, written communication, 1990). Figure 6 shows the contoured Bouguer gravity combining the new and old data. The gravity low centered on Katmai Pass spans approximately 400 square km, extends $24 \mathrm{~km}$ along the strike of the magmatic arc (NE-SW) and $16 \mathrm{~km}$ in the perpendicular direction, and reaches a minimum of -27 mGal. Both Novarupta (the vent for the 1912 Valley of Ten Thousand Smokes ash flow) and the contemporaneously formed Katmai Caldera are on the flanks of this gravity low. Mt Trident, the source of 1949 to 1963 (and later) lava flows, also lies along the margin of this low. Based on teleseismic delays observed in the local seismic network, Ward et al. (1991) concluded that the gravity low may be related to magma within the crust beneath Katmai Pass. The gravity and teleseismic anomalies at Katmai Pass are analogous to similar anomalies at the Geysers-Clear Lake region in California, an active geothermal area (Saltus et al., 1991). The correlation of low-density and low-velocity sources in a region of (presumed) high heat flow and recent volcanism strongly suggests that the anomalies are caused by magma bodies within the crust (Saltus et al., 1991).

\section{Acknowledgements}

The helicopter time for gravity data collection was paid for by the University of Alaska, Fairbanks, as part of their on-going work in the Katmai region. David Stone and Jurgen Kienle coordinated this support and provided important advice for the planning of this survey. David Barnes, USGS, Menlo Park, pointed out the need for more data in the Katmai Pass region and suggested that we should take advantage of the helicopter support already planned for seismic network maintenance. Pete Ward, USGS, Menlo Park, was the field chief for the seismic network maintenance. Mel Nading, Trans Alaska Helicopters, Anchorage, Alaska, was the expert pilot for this survey. We thank the U.S. Fish and Wildlife Office in King Salmon, Alaska, for lodging and vehicle support, and the National Park Service Office for logistical support. 


\section{References}

Barnes, D.F., 1972, Notes on the processing and presentation of U.S. Geological Survey Alaskan gravity data, U.S. Geological Survey Open-file report 72-16, 21 p.

Barnes, D.F., 1984, Digital elevation models improve processing of Alaskan gravity data, in The United States Geological Survey in Alaska: Accomplishments During 1981, U.S. Geological Survey Circular 868, Coonrad, W.L., and Elliott, R.L., eds., p. 5-7.

Eichelberger, J.C., Ballard, S., Carrigan, C.R., Goodliffe, A., Hildreth, W., Iwatsubo, E., Kasameyer, P.W., Keith, T.E.C., Kienle, J., Papike, J.J., Pollard, D.D., Stone, D.B., Wallmann, P.C., Ward, P.L., Wilt, M., and Yount, M.E., 1990, Geophysics at Katmai - Geophysical expedition to Novarupta Volcano, Katmai National Park, Alaska: EOS Transactions of the American Geophysical Union, v. 71, p. 733-735.

International Association of Geodesy, 1971, Geodetic Reference System 1967: International Association of Geodesy Special Publication, No. 3, 116 p.

Kienle, J., 1969, Gravity survey in the general area of the Katmai National Monument, Alaska: Ph.D. Dissertation, University of Alaska, $151 \mathrm{p}$.

Morelli, C., 1974, The international gravity standardization net 1971: International Association of Geodesy Special Publication 4, $194 \mathrm{p}$.

Plouff, Donald, 1977, Preliminary documentation for a FORTRAN program to compute gravity terrain corrections based on topography digitized on a geographic grid: U.S. Geological Survey Open-File Report 77-534, $45 \mathrm{p}$.

Saltus, R.W., Stone, D.B., Keinle, J., and Goodliffe, A.M., 1991, New gravity data at Katmai National Park, Alaska, suggest a magma body analogous to that at the Geysers-Clear Lake Region, California, EOS Transactions of the American Geophysical Union, v. 72, n. 44, p. 429.

Simpson, R.W., Jachens, R.C., Blakely, R.J., and Saltus, R.W., 1986, A new isostatic residual gravity map of the conterminous United States with a discussion on the significance of isostatic residual anomalies: Journal of Geophysical Research, v. 91, p. 8348-8372.

Ward, P.L., Pitt, A.M., and Endo, E., 1991, Seismic evidence for magma in the vicinity of Mt. Katmai, Alaska: Geophysical Research Letters, v. 18, p. 1537-1540. 
Appendix - Base station descriptions

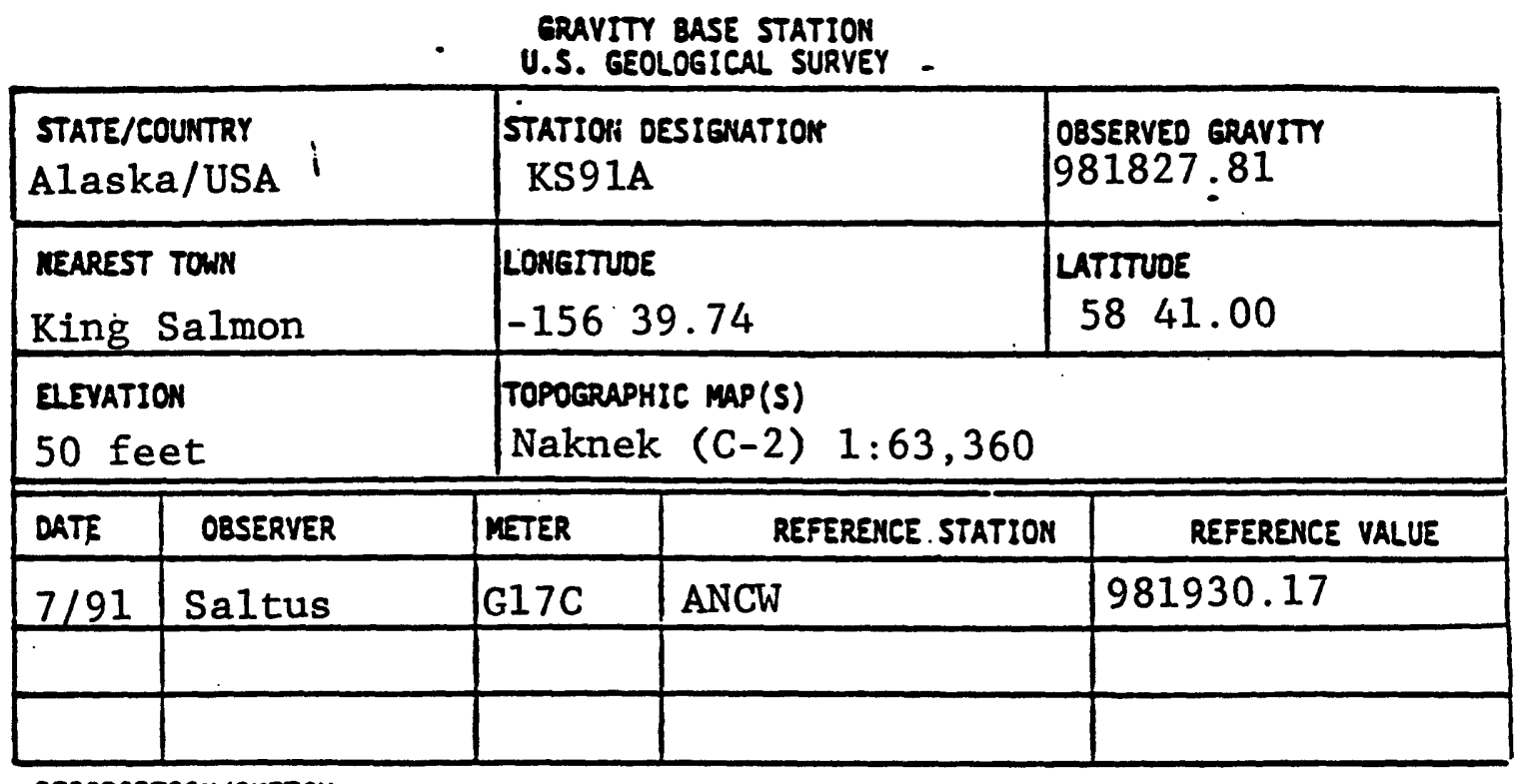

OESCRIPTION/SKETCH

The station is located on the south porch of the King Salmon Post Office (at the airport in the west part of the building that houses the Mark Air termina1). The site is in the east corner of the porch, just outside an employee service door. An aluminum USGS gravity disk stamped "KS91A" was cemented to the concrete.

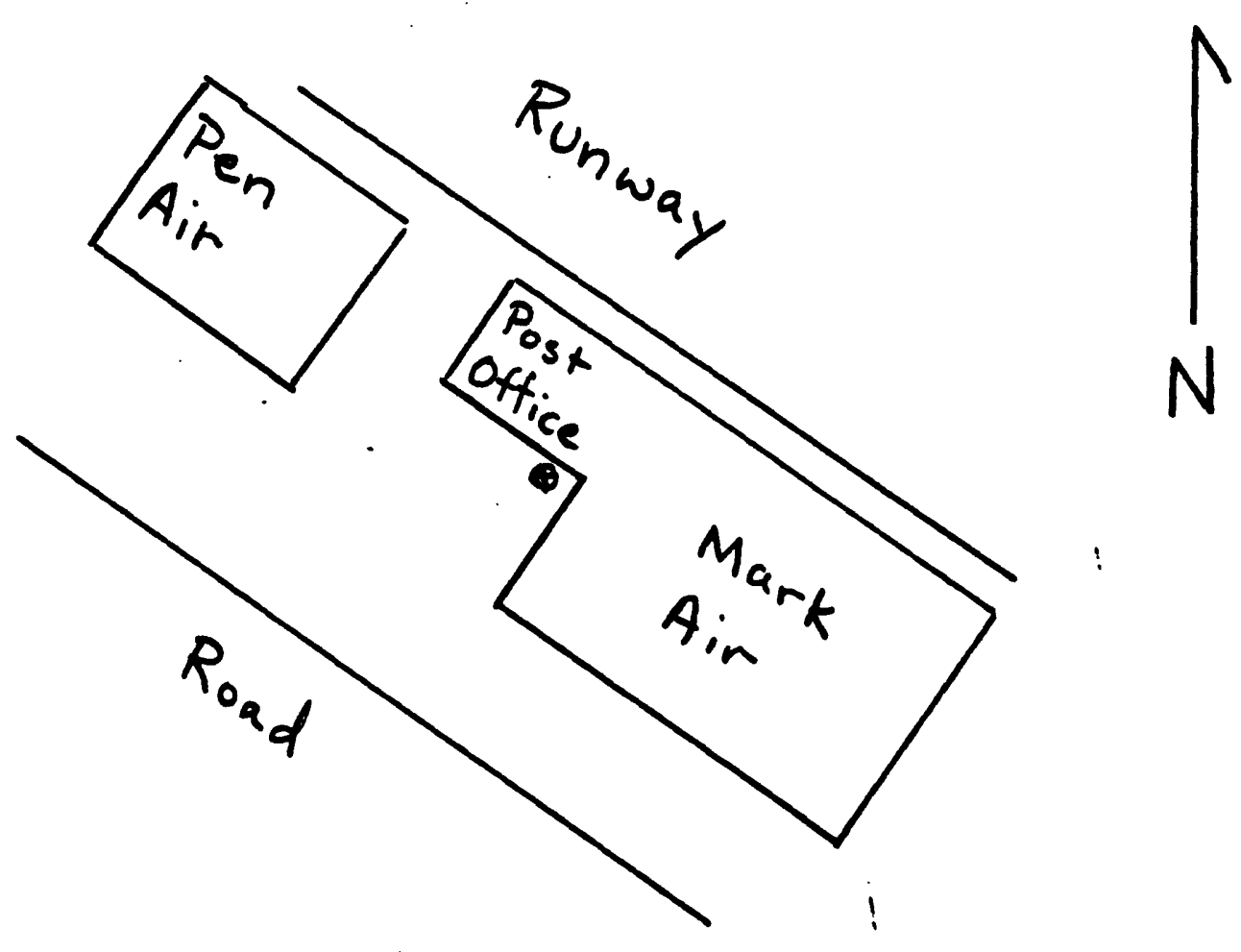




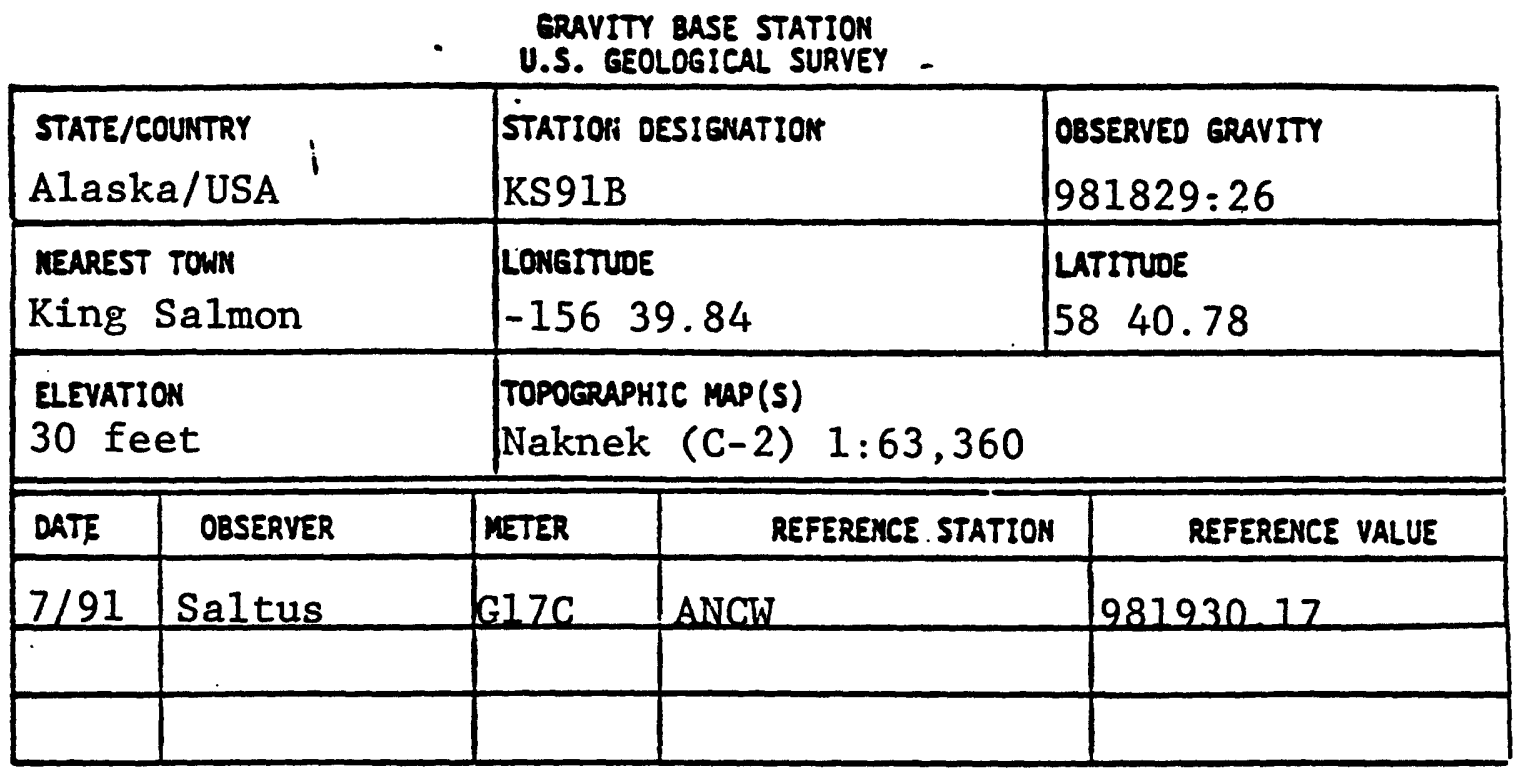

\section{DESCRIPTION/SKETCH}

The station is located on a concrete step just outside the main entrance to Building H $_{4}$ of the U.S. Fish and Wildlife Service complex next to the Naknek river in King Salmon. The site is marked with an aluminum USGS gravity disk stamped "KS91B".

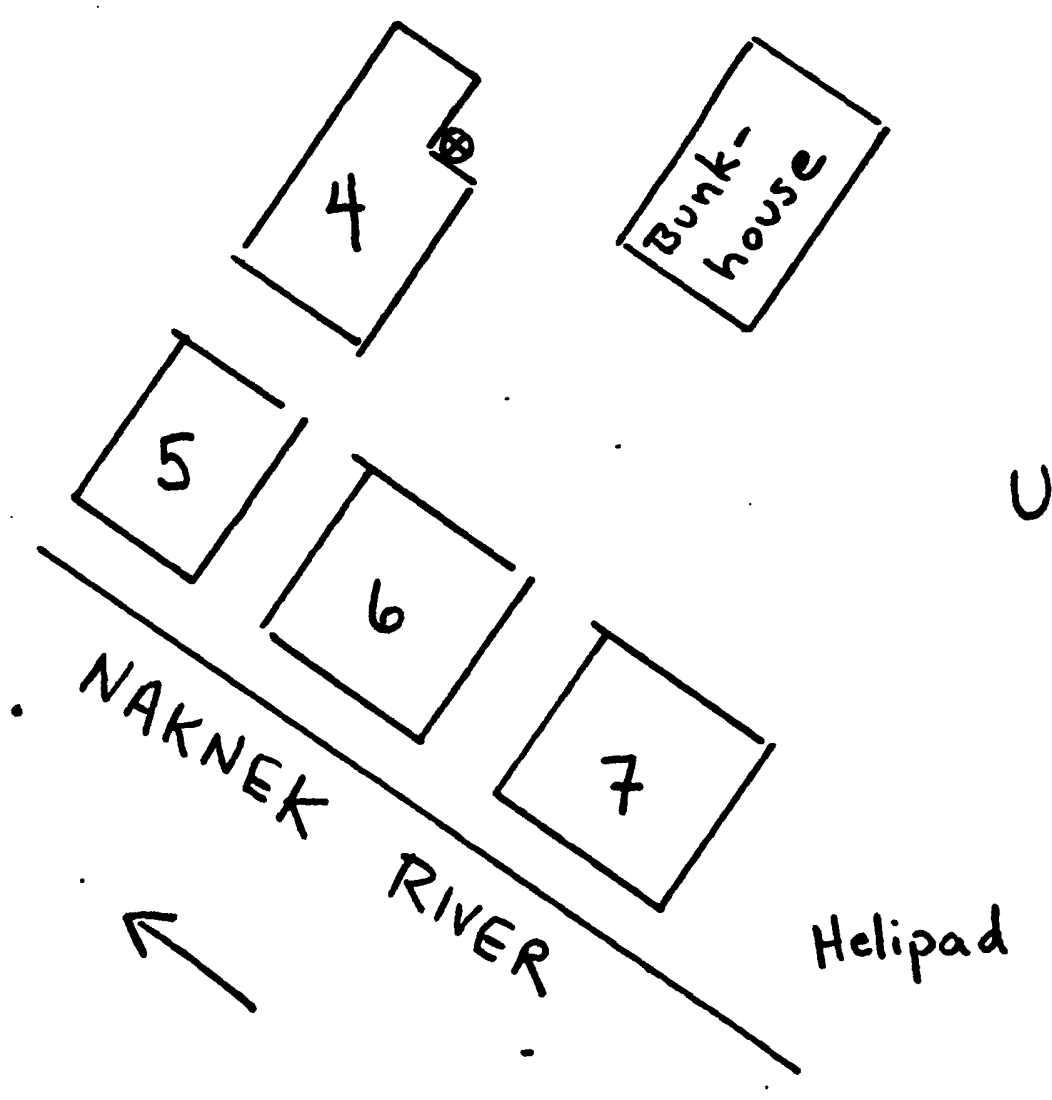

U.S. Fish and wild life Service complex 

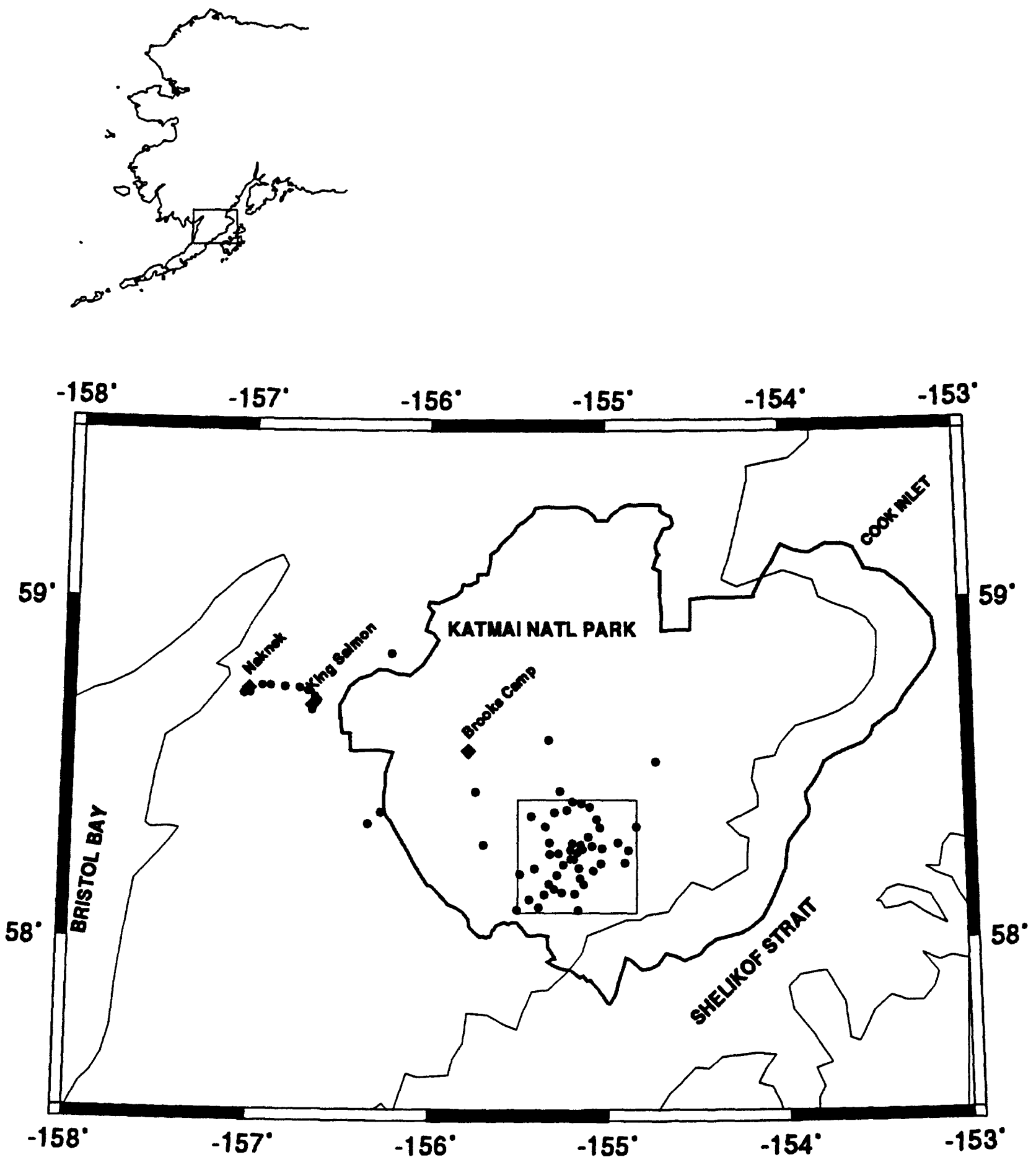

Figure 1: Location of study area in southwest Alaska. Dots show the locations of gravity measurements described in this report. The heavy line is the approximate boundary of Katmai National Park. The box shows the area of the gravity map in Figure 7. 

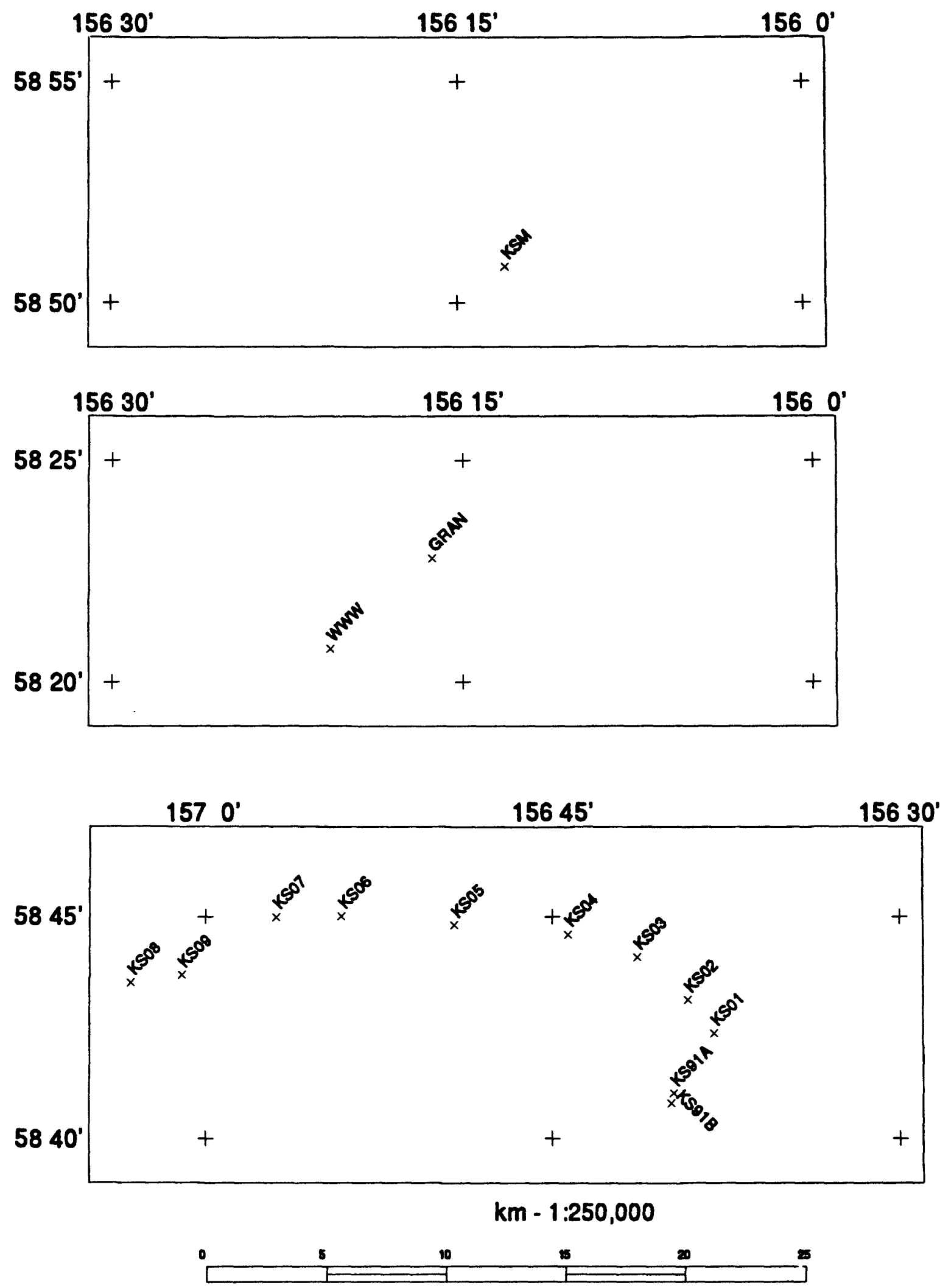

Figure 2: Gravity station locations, King Salmon to Naknek, Alaska, and western edge of Katmai National Park. 


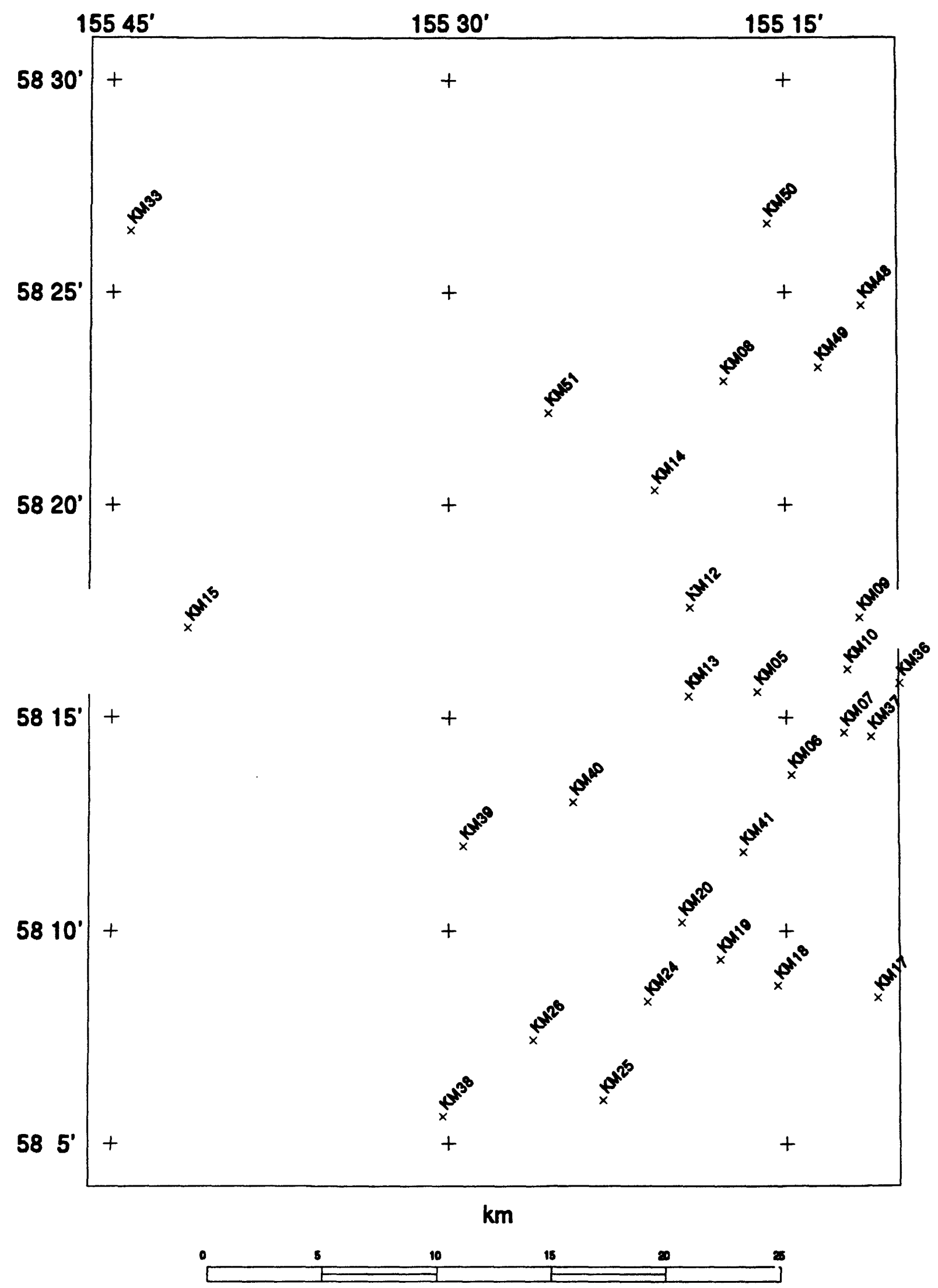

Figure 3: Gravity station locations, west Katmai National Park and vicinity. 


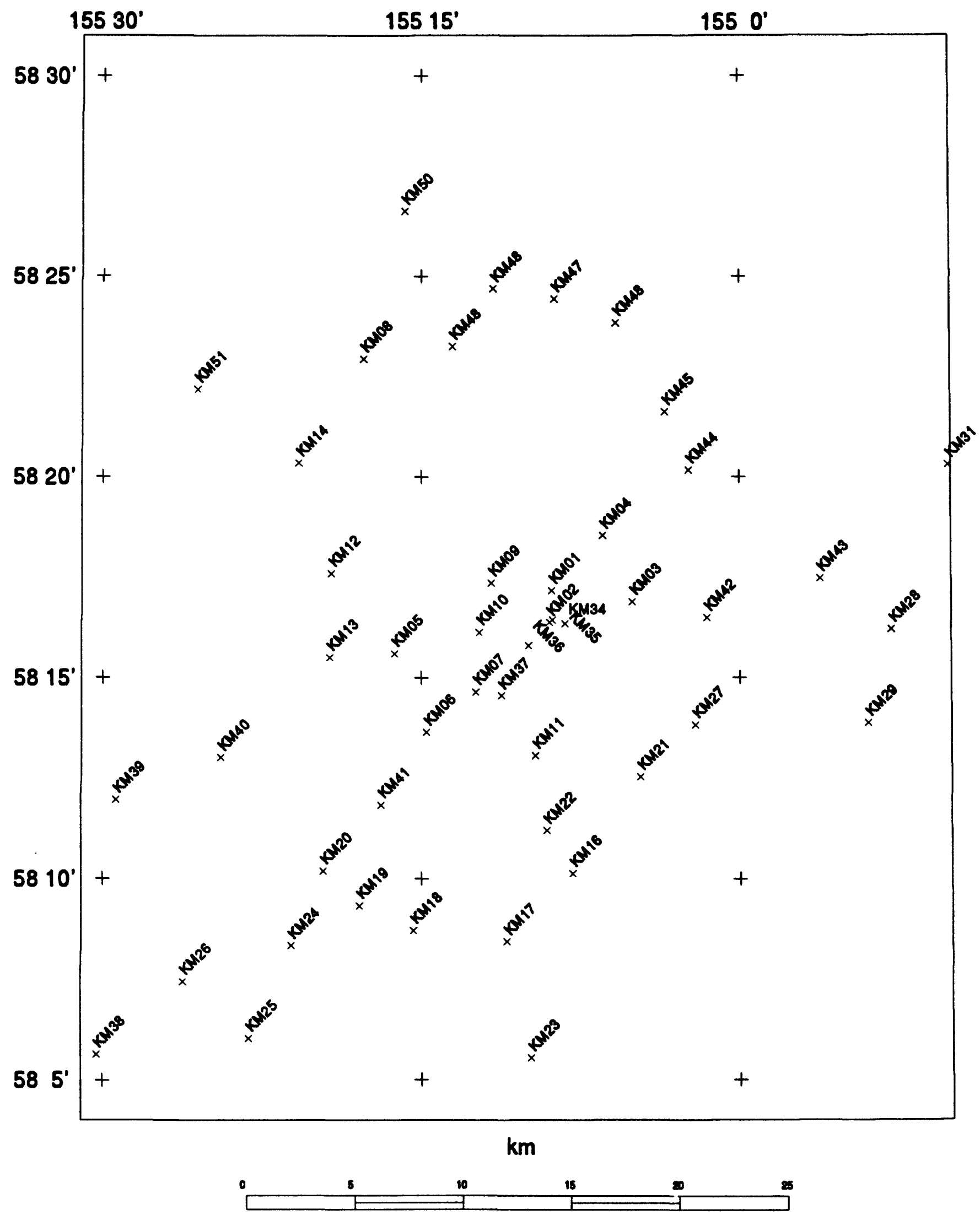

Figure 4: Gravity station locations, central Katmai National Park and vicinity. 


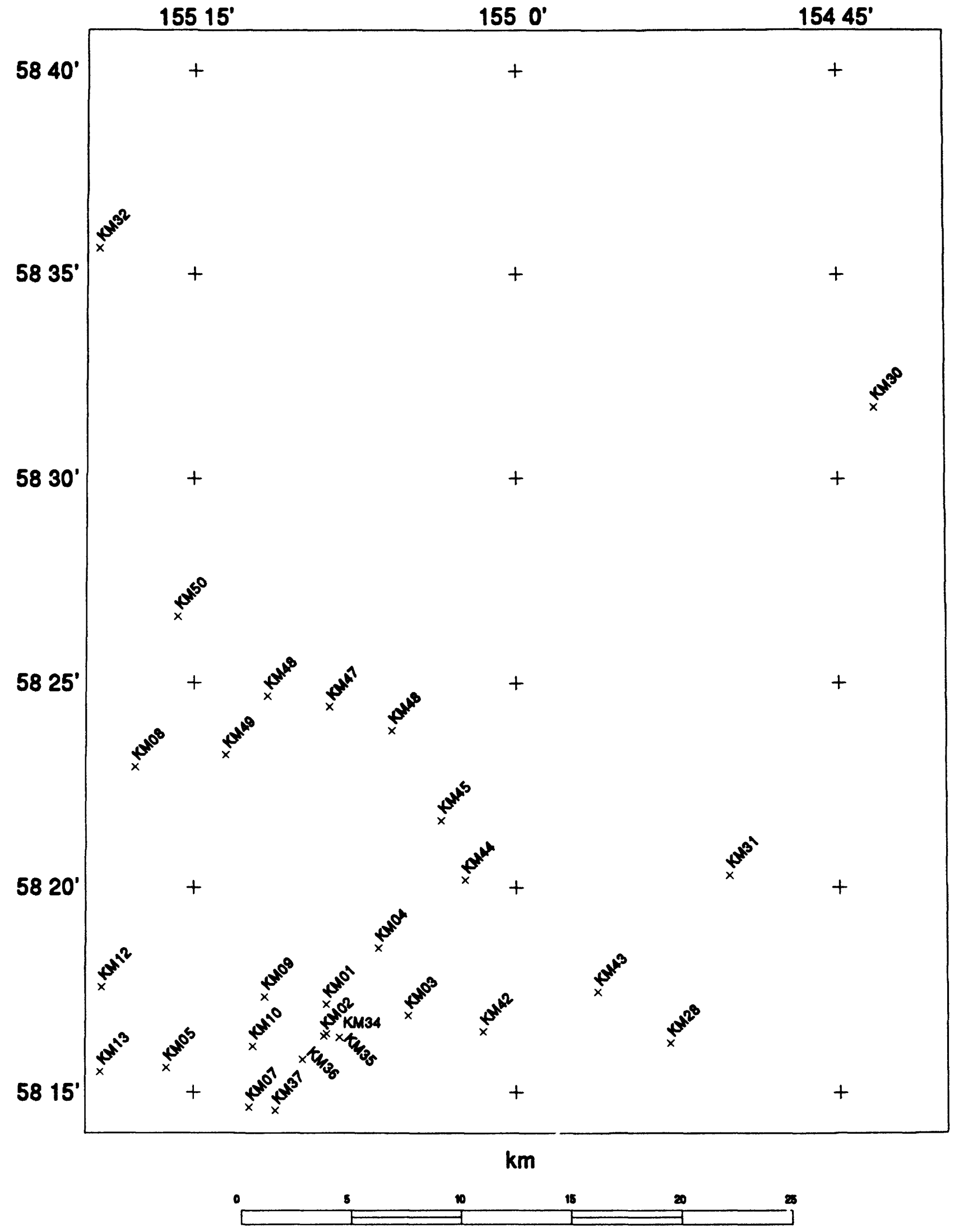

Figure 5: Gravity station locations, northeast Katmai National Park and vicinity. 


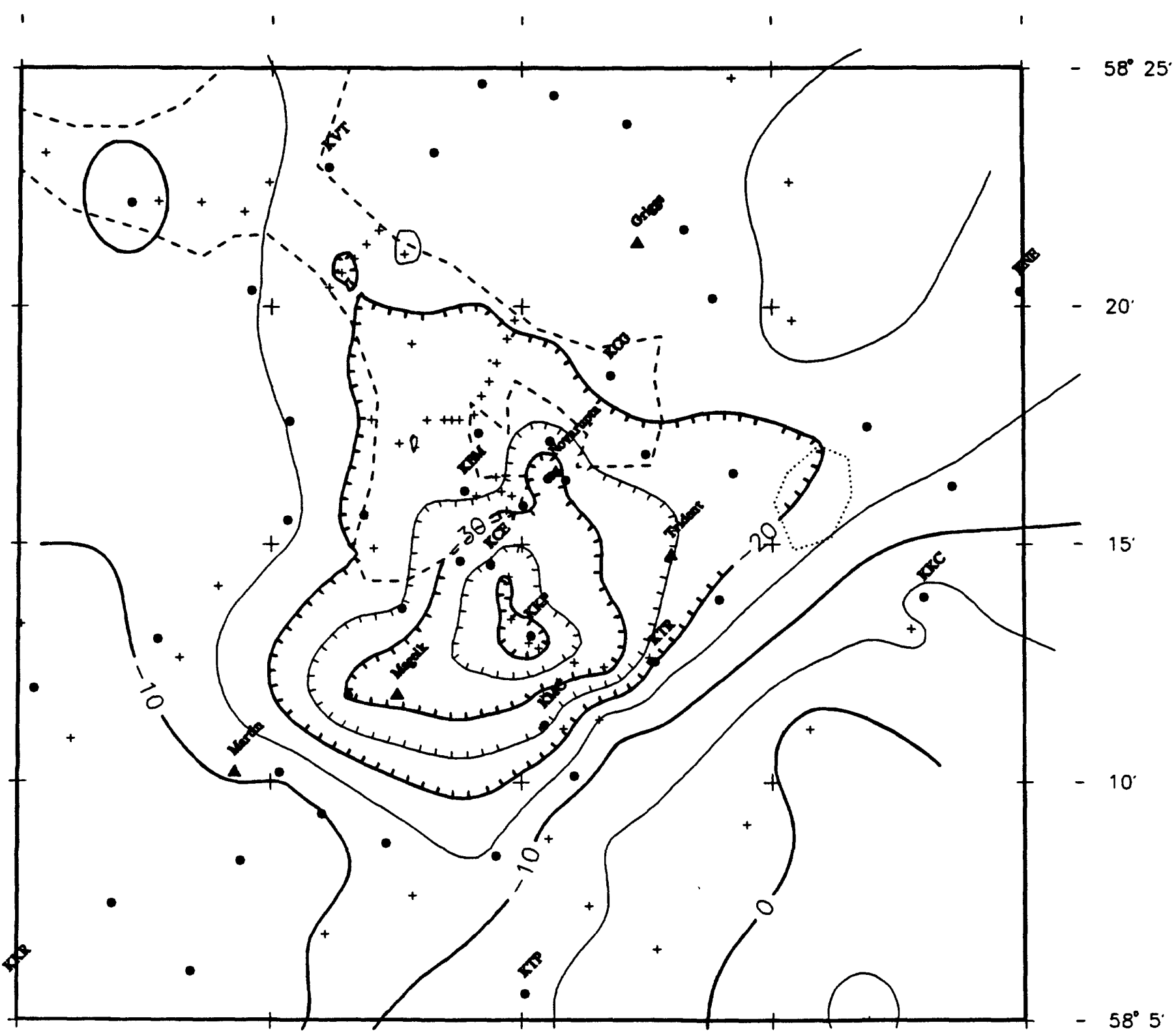

Kilometers

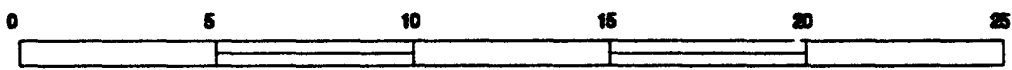

Figure 6: Complete Bouguer gravity anomaly in the vicinity of Katmai Pass, Katmai National Park, Alaska. Contour interval is $5 \mathrm{mGal}$. Dashed line t: aces the Valley of Ten Thousand Smokes, dotted line outlines Katmai Caldera. Triangles mark major volcanos. Filled circles are the locations of new gravity measurements from July 1991, pluses mark previous measurements (Keinle, 1969; David Barnes, written communication, 1990). Three-letter labels identify stations of the seismic network (Ward et al., 1991). Station KKP is located at Katmai Pass. 